\title{
The Cedar Project: risk factors for transition to injection drug use among young, urban Aboriginal people
}

\author{
Cari L. Miller PhD, Margo E. Pearce MSc, Akm Moniruzzaman PhD, Vicky Thomas, Chief Wayne Christian, \\ Martin T. Schechter MD PhD, Patricia M. Spittal PhD; for the Cedar Project Partnership
}

\begin{abstract}
- AbSTRACT
Background: Studies suggest that Aboriginal people in Canada are over-represented among people using injection drugs. The factors associated with transitioning to the use of injection drugs among young Aboriginal people in Canada are not well understood.

Methods: The Cedar Project is a prospective cohort study (2003-2007) involving young Aboriginal people in Vancouver and Prince George, British Columbia, who use illicit drugs. Participants' venous blood samples were tested for antibodies to HIV and the hepatitis $C$ virus, and drug use was confirmed using saliva screens. The primary outcomes were use of injection drugs at baseline and tranisition to injection drug use in the six months before each follow-up interview.
\end{abstract}

Results: Of 605 participants, 335 (55.4\%) reported using injection drugs at baseline. Young people who used injection drugs tended to be older than those who did not, female and in a relationship. Participants who injected drugs were also more likely than those who did not to have been denied shelter because of their drug use, to have been incar- cerated, to have a mental illness and to have been involved in sex work. Transition to injection drug use occurred among 39 (14.4\%) participants, yielding a crude incidence rate of $19.8 \%$ and an incidence density of 11.5 participants per 100 person-years. In unadjusted analysis, transition to injection drug use was associated with being female (odds ratio [OR] $1.98,95 \%$ confidence interval $(\mathrm{Cl}) 1.06-3.72)$, involved in sex work (OR 3.35, 95\% Cl 1.756.40), having a history of sexually transmitted infection (OR 2.01, 95\% Cl 1.07-3.78) and using drugs with sex-work clients (OR 2.51, $95 \% \mathrm{Cl}$ 1.19-5.32). In adjusted analysis, transition to injection drug use remained associated with involvement in sex work (adjusted OR 3.94, 95\% Cl 1.45-10.71).

Interpretation: The initiation rate for injection drug use of 11.5 participants per 100 person-years among participants in the Cedar Project is distressing. Young Aboriginal women in our study were twice as likely to inject drugs as men, and participants who injected drugs at baseline were more than twice as likely as those who did not to be involved in sex work.
Competing interests: Cari Miller, Margo Pearce, Akm Moniruzzaman, Vicky

Thomas, Chief Wayne

Christian, Martin Schechter and Patricia Spittal have received grants from the Canadian Institutes of Health Research. Wayne

Christian is the

spokesperson for the

Shuswap Nation Tribal Council. Martin Schechter is chief scientific officer for the Michael Smith

Foundation for Health Research.

This article has been peer reviewed.

Correspondence to: Patricia Spittal, spittal@sm.hivnet.ubc.ca

CMAJ 2011. DOI:10.1503 /cmaj.101257

\section{A} boriginal leadership in Canada is deeply concerned about substance use, more specifically injection drug use and its association with the spread of HIV and the hepatitis $\mathrm{C}$ virus among Aboriginal young people. ${ }^{1,2}$ Recent studies in Canada suggest that Aboriginal people are over-represented among people who use injection drugs. ${ }^{3,4}$ For Aboriginal young people in Canada under the age of 24 years, injection drug use accounts for the majority of infections with the hepatitis $\mathrm{C}$ virus $(70 \%-$ $80 \%)^{5,6}$ and over half (59\%) of HIV infections. ${ }^{7}$

Indigenous scholars have stated that research on substance use within Aboriginal communities must consider the context of colonization, including the intergenerational impacts of the residential school and child welfare systems. ${ }^{8-11}$
It is now well documented that Aboriginal children experienced extensive psychological, sexual, physical and emotional abuses within those systems. ${ }^{12,13}$ As former students of residential schools raise children and grandchildren, the intergenerational effects of abuse and familial fragmentation are evident in communities where interpersonal violence and drug dependence are pervasive. ${ }^{14-16}$

A priority for preventing infections with HIV and hepatitis $\mathrm{C}$ among young Aboriginal people is the development of programs and rights-based, ${ }^{18,19}$ youth-informed ${ }^{17}$ policies aimed at preventing the use of injection drugs. However, research to date has not provided sufficient evidence to inform such development. ${ }^{2,19}$ Concerns over this paucity of information led to the launch of a two-city 
cohort study in 2003 to address HIV-related vulnerabilities among young Aboriginal people in British Columbia - a unique study centred on atrisk youth and supported by and partnered with Aboriginal investigators and collaborators.

We report here baseline and longitudinal data on the factors associated with injection drug use and the transition to injection drug use to inform the development of prevention programs and policies.

\section{Methods}

The Cedar Project is a prospective study of young Aboriginal people who use drugs in Vancouver and Prince George, BC. The methods used in the Cedar Project study have been previously published in detail. ${ }^{2}$ Briefly, young people who self identify as Aboriginal were considered to be the descendants of the First Nation Peoples of North America, including Métis, Aboriginal, First Nations, Inuit and status and nonstatus Indians. Participants living primarily in the downtown areas of both cities were recruited through health care providers, street outreach and word of mouth. Similar to other young "atrisk" cohorts studied to explore the transmission of blood-borne diseases, our eligibility criteria included being between 14 and 30 years of age and having smoked or injected illicit drugs, other than marijuana, in the month before enrolment. ${ }^{20,21}$ Drug use was confirmed using saliva screens (Oral-screen, Avitar Onsite Diagnostics). All participants met with an Aboriginal study coordinator who explained procedures, sought informed consent and confirmed eligibility. Participants completed a detailed questionnaire administered by an interviewer at enrolment. The questionnaire was designed to elicit information on sociodemographic characteristics, patterns of drug use, sexual vulnerability and use of services. At baseline and every six months, participants completed private followup interviews. Venous blood samples were taken and tested for antibodies to HIV and the hepatitis $\mathrm{C}$ virus at each visit. Participants were offered pre- and post-test counselling with trained nurses. They were requested, but not required, to return for the results of their antibody tests. Each participant was given a $\$ 20$ stipend at each visit.

This study followed the guidelines provided in the Tricouncil Policy Statement on ethical conduct for research involving human subjects, (particularly section 6.0, which pertains to research involving Aboriginal participants) and the new Canadian Institutes of Health Research guidelines for research involving Aboriginal peoples. ${ }^{22}$ The study was approved by the University of British Columbia and Providence Health Care Research Ethics Board. Aboriginal collaborators were involved in the conception, design and interpretation of the results of this analysis.

\section{Outcome variables and covariates}

The primary outcomes in this analysis were use of injection drugs at baseline (yes or no) and starting to use injection drugs in the six months before each follow-up interview (yes or no). Participants were asked at baseline "Have you ever injected drugs?" In follow-up interviews, participants were asked "Have you injected for the first time in the last year?"

The following fixed dichotomous baseline covariates were used in the analysis: interviewed in Vancouver; sex; identifying as gay, lesbian, bisexual or two-spirited; having at least one parent who had attended residential school; ever having been placed into foster care; and ever experiencing sexual abuse. Sexual abuse was defined as any type of sexual activity into which participants had either been forced or co erced (including childhood sexual abuse, molestation, rape and sexual assault). Nonfixed (occurred in the past six months) covariates included age, being in a relationship, ever having lived on the streets for a period of three nights or more, ever having been denied shelter because of drug use, ever having attempted suicide, ever having been involved in sex work, a history of sexually transmitted infection, ever having been incarcerated overnight or longer, presence of antibodies to HIV and the hepatitis $\mathrm{C}$ virus, ever having smoked illicit drugs (marijuana, crack cocaine, opiates [heroin, morphine, methadone, talwin or dilaudid] and methamphetamine) and inconsistent use of condoms during insertive sex (vaginal, anal). Sexual assault was defined as having experienced sexual violence in the past six months. Sex work was defined as receiving money, shelter, food or drugs in exchange for sex.

\section{Analysis}

We analyzed the results of the baseline questionnaires from all participants $(n=605)$ at baseline in 2003 and data from participants who reported no history of injection drug use at baseline and who returned for at least one of five follow-up interviews $(n=197)$ up to 2007 . We compared the baseline categorical variables between participants who reported a history of injection drug use and participants who did not using Pearson $\chi^{2}$ test and Fisher exact tests when expected cell values were less than five. We analyzed continuous variables using the Wilcoxon rank-sum test 
Table 1: Characteristics and vulnerabilities of participants of the Cedar Project Study who reported injection drug use at baseline and participants who did not

\begin{tabular}{|c|c|c|c|}
\hline \multirow[b]{2}{*}{ Characteristic or vulnerability } & \multicolumn{2}{|c|}{ No. $(\%)^{*}$} & \multirow[b]{2}{*}{$p$ value } \\
\hline & $\begin{array}{l}\text { Used injection drugs } \\
\qquad n=335\end{array}$ & $\begin{array}{l}\text { Never used injection drugs } \\
\qquad n=270\end{array}$ & \\
\hline Age at enrolment, yr, mean (SD) & $24.6(3.7)$ & $22.2(4.1)$ & $<0.001$ \\
\hline Interviewed in Vancouver & $\begin{array}{c}n=335 \\
175 \quad(52.2)\end{array}$ & $\begin{array}{c}n=270 \\
125 \quad(46.3)\end{array}$ & 0.15 \\
\hline Female sex & $\begin{array}{c}n=335 \\
189 \quad(56.4)\end{array}$ & $\begin{array}{c}n=270 \\
103 \quad(38.1)\end{array}$ & $<0.001$ \\
\hline $\begin{array}{l}\text { Identifying as gay, lesbian, } \\
\text { bisexual or two-spirited }\end{array}$ & $\begin{array}{l}n=334 \\
46 \quad(13.8)\end{array}$ & $\begin{array}{l}n=270 \\
21 \quad(7.8)\end{array}$ & 0.02 \\
\hline In a relationship & $\begin{array}{l}n=335 \\
96 \quad(28.7)\end{array}$ & $\begin{array}{l}n=269 \\
46(17.1)\end{array}$ & 0.001 \\
\hline $\begin{array}{l}\text { At least one parent attended } \\
\text { residential school }\end{array}$ & $\begin{array}{c}n=332 \\
167 \quad(50.3)\end{array}$ & $\begin{array}{c}n=269 \\
111(41.3)\end{array}$ & 0.03 \\
\hline Ever placed in foster care & $\begin{array}{c}n=335 \\
215 \quad(64.2)\end{array}$ & $\begin{array}{c}n=270 \\
176 \quad(65.2)\end{array}$ & 0.80 \\
\hline Ever experienced sexual abuse & $\begin{array}{c}n=332 \\
179 \quad(53.9)\end{array}$ & $\begin{array}{c}n=265 \\
109(41.1)\end{array}$ & 0.002 \\
\hline Sexual assault in the past 6 mo & $\begin{array}{l}n=335 \\
18 \quad(5.4)\end{array}$ & $\begin{array}{l}n=270 \\
7 \quad(2.6)\end{array}$ & 0.10 \\
\hline Lived on the street for $\geq 3$ nights & $\begin{array}{c}n=333 \\
239 \quad(71.8)\end{array}$ & $\begin{array}{c}n=269 \\
168 \quad(61.7)\end{array}$ & 0.01 \\
\hline $\begin{array}{l}\text { Ever denied shelter because of } \\
\text { drug use }\end{array}$ & $\begin{array}{cc}n= & 335 \\
113 & (33.7)\end{array}$ & $\begin{array}{l}n=269 \\
50 \quad(18.6)\end{array}$ & $<0.001$ \\
\hline $\begin{array}{l}\text { Ever incarcerated overnight or } \\
\text { longer }\end{array}$ & $\begin{array}{c}n=334 \\
248 \quad(74.3)\end{array}$ & $\begin{array}{c}n=147 \\
147(54.4)\end{array}$ & $<0.001$ \\
\hline Ever attempted suicide & $\begin{array}{c}n=334 \\
136 \quad(40.7)\end{array}$ & $\begin{array}{l}n=270 \\
88 \quad(32.6)\end{array}$ & 0.04 \\
\hline Ever practised self harm & $\begin{array}{c}n=332 \\
129 \quad(38.9)\end{array}$ & $\begin{array}{c}n=270 \\
101 \quad(37.4)\end{array}$ & 0.72 \\
\hline History of mental illness & $\begin{array}{c}n=334 \\
112 \quad(33.5)\end{array}$ & $\begin{array}{l}n=268 \\
70(26.1)\end{array}$ & 0.05 \\
\hline Ever involved in sex work & $\begin{array}{c}n=335 \\
180 \quad(70.0)\end{array}$ & $\begin{array}{l}n=268 \\
77(30.0)\end{array}$ & $<0.001$ \\
\hline $\begin{array}{l}\text { History of sexually transmitted } \\
\text { infection }\end{array}$ & $\begin{array}{c}n=335 \\
163 \quad(48.7)\end{array}$ & $\begin{array}{l}n=270 \\
84(31.1)\end{array}$ & $<0.001$ \\
\hline $\begin{array}{l}\text { Smoked marijuana in the past } \\
6 \text { mo }\end{array}$ & $\begin{array}{c}n=335 \\
220 \quad(65.7)\end{array}$ & $\begin{array}{c}n=270 \\
200(74.1)\end{array}$ & 0.03 \\
\hline $\begin{array}{l}\text { Smoked crack cocaine in the past } \\
6 \text { mo }\end{array}$ & $\begin{array}{l}n=335 \\
301 \quad(89.9)\end{array}$ & $\begin{array}{c}n=270 \\
241(89.3)\end{array}$ & 0.81 \\
\hline Smoked heroin in the past 6 mo & $\begin{array}{c}n=335 \\
107 \quad(32.9)\end{array}$ & $\begin{array}{l}n=270 \\
33(12.2)\end{array}$ & $<0.001$ \\
\hline $\begin{array}{l}\text { Smoked methamphetamine in the } \\
\text { past } 6 \text { mo }\end{array}$ & $\begin{array}{c}n=335 \\
105 \quad(31.3)\end{array}$ & $\begin{array}{l}n=270 \\
87(32.2)\end{array}$ & 0.82 \\
\hline $\begin{array}{l}\text { Tried to access treatment for drug } \\
\text { abuse in the past } 6 \text { mo }\end{array}$ & $\begin{array}{l}n=334 \\
59(17.7)\end{array}$ & $\begin{array}{l}n=270 \\
33(12.2)\end{array}$ & 0.06 \\
\hline $\begin{array}{l}\text { Treatment with methadone in the } \\
\text { past } 6 \text { mo }\end{array}$ & $\begin{array}{l}n=333 \\
32 \quad(9.6)\end{array}$ & $\begin{array}{l}n=269 \\
2(0.7)\end{array}$ & $<0.001$ \\
\hline Presence of antibodies to HCV & $\begin{array}{c}n=311 \\
181 \quad(58.2)\end{array}$ & $\begin{array}{l}n=257 \\
8(3.1)\end{array}$ & $<0.001$ \\
\hline Presence of antibodies to HIV & $\begin{array}{l}n=324 \\
39(12.0)\end{array}$ & $\begin{array}{l}n=265 \\
8(17.0)\end{array}$ & $<0.001$ \\
\hline
\end{tabular}


and Student $t$ test. We used logistic regression to model odds ratios (ORs) for associations between independent variables and the likelihood of using injection drugs at baseline.

We calculated the cumulative incidence rate for starting to use injection drugs using the Kaplan-Meier method. We defined time zero as the date participants enrolled in the study. Participants who consistently reported throughout the study period that they had never used injection drugs were considered right censored at the time of their most recent follow-up interview. We used Cox proportional hazards regression with time-dependent covariates to estimate hazard ratios (HRs) for associations between time to start of injection drug use and the study variables. All reported $p$ values are two-sided. All variables that were significant at $p=0.05$ were entered into the multivariable logistic regression model.

\section{Results}

In total, 605 Aboriginal young people responded to the baseline questionnaire. The median age of participants was 23 years, and $292(48.3 \%)$ of the the participants were women. At enrolment, 335 (55.4\%) participants

Table 2: Unadjusted and adjusted associations with injection drug use at baseline for 605 participants of the Cedar Project in British Columbia, Canada

\begin{tabular}{|c|c|c|}
\hline \multirow[b]{2}{*}{ Variable } & \multicolumn{2}{|c|}{ OR $(95 \% \mathrm{Cl}) *$} \\
\hline & Unadjusted & Adjusted \\
\hline Age & $1.17(1.12-1.22) \dagger$ & $1.18(1.12-1.24) \dagger$ \\
\hline Female sex & $2.10(1.51-2.91) \dagger$ & $2.44(1.48-4.01) \dagger$ \\
\hline $\begin{array}{l}\text { Identifying as gay, lesbian, bisexual } \\
\text { or two spirited }\end{array}$ & $1.89(1.10-3.26)$ & $1.34(0.67-2.65)$ \\
\hline In a relationship & $1.95(1.31-2.89) \ddagger$ & $1.69(1.07-2.68) \S$ \\
\hline $\begin{array}{l}\text { At least one parent attended } \\
\text { residential school }\end{array}$ & $1.44(1.04-1.99)$ & $1.27(0.87-1.86)$ \\
\hline Ever experienced sexual abuse & $1.67(1.20-2.32)$ & $0.77(0.50-1.18)$ \\
\hline Lived on the street for $\geq 3$ nights & $1.58(1.12-2.22)$ & $0.97(0.63-1.45)$ \\
\hline $\begin{array}{l}\text { Ever denied shelter because of drug } \\
\text { use }\end{array}$ & $2.23(1.52-3.27) \dagger$ & $1.59(1.01-2.51) \S$ \\
\hline $\begin{array}{l}\text { Ever incarcerated overnight or } \\
\text { longer }\end{array}$ & $2.41(1.71-3.40) \dagger$ & $2.95(1.92-4.54) \dagger$ \\
\hline Ever attempted suicide & $1.42(1.02-1.99)$ & $1.04(0.69-1.57)$ \\
\hline History of mental illness & $1.43(1.00-2.04) \S$ & $1.56(1.01-2.41) \S$ \\
\hline Ever involved in sex work & $2.89(2.05-4.05) \dagger$ & $2.30(1.43-3.69) \ddagger$ \\
\hline \multicolumn{3}{|c|}{$\begin{array}{l}\text { Note: } \mathrm{Cl}=\text { confidence interval, } \mathrm{OR}=\text { odds ratio. } \\
{ }^{*} \mathrm{OR}<1.00 \text { shows an effect size that is protective for the exposed group; } \mathrm{OR}>1.00 \text { shows an } \\
\text { effect size that is higher among members of the exposed group than members of the } \\
\text { reference group. } \\
\text { †Significant at } p<0.001 . \\
\text { ‡Significant at } p<0.01 . \\
\text { SSignificant at } p<0.05 \text {. }\end{array}$} \\
\hline
\end{tabular}

reported a history of injection drug use. Table 1 compares the baseline characteristics and vulnerabilities between participants who had previously used injection drugs and those who had not. Participants who had injected drugs were older than participants who had not. Participants who had used injection drugs were also more likely than nonusers to be women, to identify as gay, lesbian, bisexual or two-spirited, to be in a relationship, to have been sexually abused, to have a parent who had attended residential school, to have lived on the street for more than three nights, to have been denied shelter because of drug use, to have been incarcerated, to have attempted suicide, to have a history of mental illness, to have had a sexually transmitted infection, to have been involved in sex work, to have smoked heroin in the past six months and to have antibodies for HIV or the hepatitis $\mathrm{C}$ virus. Participants who reported having injected drugs were less likely to have smoked marijuana in the previous six months than participants who had not injected drugs.

\section{Injection drug use at baseline}

Table 2 shows the unadjusted and adjusted ORs, 95\% confidence intervals (CIs) and $p$ values for the multivariable model. Associations with injection drug use that reached statistical significance included age (adjusted OR 1.18, 95\% CI 1.12-1.24), being a woman (adjusted OR 2.44, 95\% CI 1.48-4.01), being in a relationship (adjusted OR 1.69, 95\% CI 1.07-2.68), having been denied shelter because of drug use (adjusted OR 1.59, 95\% CI 1.01-2.51), history of incarceration (adjusted OR 2.95, 95\% CI 1.924.54) or mental illness (adjusted OR 1.56, 95\% CI 1.01-2.41) and ever having been involved in sex work (adjusted OR 2.30, 95\% CI 1.43-3.69).

\section{Transition to injection drug use}

Of the 270 participants who reported no history of injection drug use at baseline, 197 (73\%) attended at least one follow-up visit before July 2007. The 73 participants who were lost to follow-up were similar to those who were followed in terms of age, infection with HIV or hepatitis $\mathrm{C}$ virus, relationship status, use of condoms, patterns of drug use, experiencing childhood sexual abuse and experiencing sexual assault in the previous six months. However, those participants lost to follow-up were less likely to have been placed in foster care or to have a parent who had attended residential school, and they were marginally less likely to be involved in sex work.

Of the 197 participants with follow-up informa- 
tion, 39 (18 men, 21 women) reported transition to injection drug use. This information yielded a crude incidence rate for injection drug use of $19.8 \%$ and an incidence density of 11.5 cases per 100 person-years (95\% CI 8.2-17.5). The median age at first injection among new users was 22.1 years (interquartile range 17.7-31.2 years).

Table 3 summarizes the results of our unadjusted and adjusted Cox regression analyses. In unadjusted analysis, factors associated with transition to injection drug use were being a woman (HR 1.98, 95\% CI 1.06-3.72), involvement in sex work in the past six months (HR 3.35, 95\% CI 1.75-6.40), using drugs with sex work clients in the past six months (HR 2.51, 95\% CI 1.19-5.32) and a history of sexually transmitted infection in the past six months (HR 2.01, 95\% CI 1.07-3.78). All variables significant at $p \leq 0.05$ in unadjusted analysis were entered into the adjusted model. After adjustment,

Table 3: Variables associated with the risk of transition to injection drug use $(n=39)$ among the 197 participants of the Cedar Project in British Columbia, Canada, for whom follow-up information was available

\begin{tabular}{|c|c|c|}
\hline \multirow[b]{2}{*}{ Variable } & \multicolumn{2}{|c|}{$\operatorname{HR}(95 \% \mathrm{Cl}) *$} \\
\hline & Unadjusted & Adjusted \\
\hline Interviewed in Prince George, BC & $0.99(0.53-1.85)$ & - \\
\hline Female sex & $1.98(1.06-3.72) \dagger$ & $1.03(0.46-2.29)$ \\
\hline Mean age at enrolment & $1.03(0.96-1.11)$ & - \\
\hline Identifying as gay, lesbian, bisexual or two-spirited & $1.97(0.77-5.04)$ & - \\
\hline At least one parent attended residential school & $0.78(0.41-1.48)$ & - \\
\hline Ever placed in foster care & $1.37(0.67-2.81)$ & - \\
\hline In a relationship during the past 6 mo & $0.62(0.30-1.31)$ & - \\
\hline Ever experienced sexual abuse & $1.24(0.66-2.34)$ & - \\
\hline Sexual assault in the past 6 mo & $0.88(0.12-6.40)$ & - \\
\hline Lived on the street for $\geq 3$ nights & $0.97(0.51-1.83)$ & - \\
\hline Ever denied shelter because of drug use & $0.95(0.42-2.15)$ & - \\
\hline Ever incarcerated overnight or longer & $0.87(0.47-1.64)$ & - \\
\hline Ever attempted suicide & $1.13(0.58-2.19)$ & - \\
\hline Ever practised self harm & $0.64(0.32-1.28)$ & - \\
\hline History of mental illness & $1.30(0.65-2.62)$ & - \\
\hline Involved in sex work in the past 6 mo & $3.35(1.75-6.40) \ddagger$ & $3.94(1.45-10.71) \ddagger$ \\
\hline $\begin{array}{l}\text { Inconsistent use of condoms with casual partner in } \\
\text { the past } 6 \text { mo }\end{array}$ & $0.96(0.40-2.29)$ & - \\
\hline $\begin{array}{l}\text { Inconsistent use of condoms with regular partner in } \\
\text { the past } 6 \text { mo }\end{array}$ & $1.25(0.67-2.36)$ & - \\
\hline $\begin{array}{l}\text { Inconsistent use of condoms with clients in the past } \\
6 \text { mo }\end{array}$ & $2.69(0.64-11.29)$ & - \\
\hline Use of drugs with clients in the past 6 mo & $2.51(1.19-5.32) \S$ & $0.64(0.23-1.82)$ \\
\hline $\begin{array}{l}\text { History of sexually transmitted infection in the past } \\
6 \text { mo }\end{array}$ & $2.01(1.07-3.78) \dagger$ & $1.72(0.88-3.37)$ \\
\hline Smoked crack cocaine daily in the past 6 mo & $1.69(0.89-3.19)$ & - \\
\hline Smoked heroin daily in the past 6 mo & $1.72(0.53-5.59)$ & - \\
\hline Smoked methamphetamine daily in the past 6 mo & $1.22(0.53-5.59)$ & - \\
\hline Ever received treatment for addiction & $1.37(0.70-2.66)$ & - \\
\hline $\begin{array}{l}\text { Tried to access treatment for addiction in the past } \\
6 \mathrm{mo}\end{array}$ & $1.20(0.62-2.31)$ & - \\
\hline Received treatment with methadone in the past $6 \mathrm{mo}$ & $1.23(0.17-8.97)$ & - \\
\hline \multicolumn{3}{|c|}{$\begin{array}{l}\text { Note: } \mathrm{BC}=\text { British Columbia, } \mathrm{Cl}=\text { confidence interval, } \mathrm{HR}=\text { hazard ratio. } \\
\text { * } \mathrm{HR}<1.00 \text { shows an effect size that is protective for the exposed group; } \mathrm{HR}>1.00 \text { indicates an effect size that is higher among } \\
\text { members of the exposed group than members of the reference group. } \\
\text { tSignificant at } p<0.05 \text {. } \\
\text { +Significant at } p<0.001 \text {. } \\
\text { §Significant at } p<0.01 \text {. }\end{array}$} \\
\hline
\end{tabular}


the only factor that remained associated with transition to injection drugs was involvement in sex work in the previous six months (adjusted HR 3.94 [95\% CI 1.45-10.71]). The results were essentially unchanged when we conducted a similar Cox regression analysis restricted to female participants. The size of our sample population was not large enough to do a full subanalysis of men who had been involved in sex work during the study period and had transitioned to injection drug use $(22.2 \%$ [4 out of 18 participants]). The Cox regression model restricted to male participants was therefore unstable owing to the limited size of our sample.

\section{Interpretation}

In our study population, about 11 participants per 100 person-years will transition to injection drug use - a rate that is almost twice as high as that found in the only other available longitudinal study done in Canada investigating transition to injection drug use among young people (6.8 per 100 person-years in Montréal, Quebec). ${ }^{20}$ Transition to injection drug use at a young age not only increases the risk of contracting an infectious disease, it also further entrenches the young person in an increasingly dangerous street life that often involves sex work, violence, predation and life-long addiction. Culturally safe interventions to prevent young Aboriginal people, especially young women, from starting to use injection drugs and reduce harm are urgently required.

Injection drug use greatly increases a person's risk for infection with hepatitis $\mathrm{C}$ virus and HIV, as well as the potential for further traumatic health outcomes among young Aboriginal people. ${ }^{2,23}$ The hepatitis $\mathrm{C}$ virus is acquired rapidly, often within two years of starting to use injection drugs, and the risk for infection with HIV increases with age. ${ }^{24}$ Subsequently, the window of opportunity to intervene after someone starts to use injection drugs is small. As such, the prioritization of public health resources needs to be toward the development of innovative prevention programs that confront the interconnected epidemics of sexual abuse, sex work, homelessness, injection drug use and infection with hepatitis $\mathrm{C}$ virus and HIV among Aboriginal young people. ${ }^{25}$

\section{Comparison with other studies}

The prevalence of injection drug use at baseline among participants of the Cedar Project (55.4\%) was higher than the rate found in two other cohort studies of young people surviving on the streets of Vancouver $(41.1 \%)^{20}$ and Montréal
(44\%). ${ }^{21}$ Young Aboriginal women in our study were twice as likely to inject drugs as their male counterparts, and their rate of use was higher than the rates seen in other comparable studies. ${ }^{26,27} \mathrm{Par}-$ ticipants who injected drugs at baseline were more than twice as likely to be involved in sex work, and participants who were involved in sex work had four times the risk of transitioning to injection drug use. For young women fleeing sexual abuse, it is possible that exchanging sex for money, shelter or drugs provides a temporary escape mechanism and is perceived as being under the young woman's control. ${ }^{28,29}$ Our results highlight the multiple dimensions of risk for transitioning to injection drug use among young Aboriginal women, which include vulnerability, sexual abuse, sex work and addiction. ${ }^{30,31}$

Historical and sexual traumas may compel young Aboriginal people to experiment with injection drugs to numb feelings of shame and isolation..$^{32}$ Many of the young people involved in this study had been removed from the care of their biological parents $(55.0 \%$ [333 of 605 participants]) and may be unaware of the intergenerational effects of the residential school system on themselves, their families and their communities. ${ }^{13}$ The baseline finding that young Aboriginal people who use injection drugs were more likely to have been incarcerated, to struggle with mental health issues and to have been denied shelter because of their drug use highlights the need for public health to move beyond the criminalization of young people who use illicit drugs, particularly if one considers trauma as a factor for the initiation of injection drugs. Providing young Aboriginal people with opportunities to learn about the role of historical trauma in addiction is imperative. ${ }^{17,19}$ Many Aboriginal AIDS and addiction services recognize the importance of "culture as intervention" and support intervention programs that are founded upon histories of resilience and resistance.

\section{Limitations}

Attaining a probabilistic sample among young people who use drugs is challenging. Our sampling within the downtown areas of Vancouver and Prince George may have under-represented young Aboriginal people who remain outside of these urban centres. ${ }^{2}$

A follow-up rate of $73 \%$ might initially seem low, but it is actually remarkable given the transient and marginalized nature of the population involved in our study. Participants lost to follow up did not differ at baseline from those followed with respect to risk. However, those lost to follow up were less likely to have been placed in foster care, to have a parent who 
had attended a residential school or to be involved in sex work. The absence of these participants from our follow up could have inflated the observed rate with which participants started to use injection drugs.

Participants were given repeated opportunities for counselling before and after their HIV tests, which might have lowered the rate of transition to injection drug use and other risks.

Because much of the data acquired in this study was based on self-report, stigmatizing or painful issues may have been under reported; if so, our results would be biased toward the null and the strength of associations might be greater than we see here. We attempted to minimize any reporting bias through the extensive training of our Aboriginal interviewers, assurances of confidentiality and availability of support services.

Considerable collinearity may exist between the historical and behavioural variables. Together with the relatively low number of transition events, this collinearity might have obscured the associations with historical trauma that we have reported.

\section{Conclusion}

This study documents an unacceptable number of young, at-risk Aboriginal people transitioning to injection drug use every year; however, there are no prevention programs tailored specifically to this population. Support for communitybased programs that address the potential for drug dependence within the context of sexual trauma should be prioritized to respond to the dual epidemics of injection drug use and bloodborne infection among Aboriginal people..$^{1,33}$

\section{References}

1. Chansonneuve D. Addictive behaviours among aboriginal people in Canada. Ottawa, (ON): Aboriginal Healing Foundation; 2007.

2. Spittal PM, Craib KJP, Teegee M, et al. The Cedar project: prevalence and correlates of HIV infection among young Aboriginal people who use drugs in two Canadian cities. Int J Circumpolar Health 2007;66:226-40 Available: www.ncbi.nlm.nih .gov/pubmed/17655063 (accessed 2007 Nov. 10).

3. Craib KJ, Spittal PM, Wood E, et al. Risk factors for elevated HIV incidence among Aboriginal injection drug users in Vancouver. CMAJ 2003;168:19-24.

4. Wood E, Lloyd-Smith E, Li K, et al. Frequent needle exchange use and HIV incidence in Vancouver, Canada. Am J Med 2007; 120:172-9.

5. Public Health Agency of Canada. Population-specific HIV/AIDS status report: Aboriginal peoples. Ottawa (ON): The Agency; 2010.

6. Craib KJ, Spittal PM, Patel SH, et al. Prevalence and incidence of hepatitis $\mathrm{C}$ virus infection among Aboriginal young people who use drugs: results from the Cedar Project. Open Medicine 2009;3:220-7

7. Public Health Agency of Canada. HIV/AIDS Epi Updates Ottawa (ON): The Agency; 2007. p.140.

8. Dickenson OP. Canada's First Nations: a history of founding peoples from earliest times. 3rd ed. Don Mills (ON): Oxford University Press; 2002.

9. Waldram JB, Herring A, Young TK. Aboriginal health in Canada: historical, cultural, and epidemiological perspectives. 2nd ed. Toronto (ON): University of Toronto Press; 2006.

10. Simoni JM, Sehgal S, Walters KL. Triangle of risk: urban American Indian women's sexual trauma, injection drug use, and HIV sexual risk behaviors. AIDS Behav 2004;8:33-45.

11. Walters KL, Simoni JM. Reconceptualizing Native women's health: an "indigenist" stress-coping model. Am J Public Health 2002;92:520-4

12. Milloy JS. A national crime: the Canadian Government and the residential school system, 1879 to 1986 . Winnipeg (MA): The University of Manitoba Press; 1999.

13. Fournier S, Crey E. Stolen from our embrace: the abduction of First Nations children and the restoration of Aboriginal communities. Vancouver (BC): Douglas \& McIntyre; 1997.

14. Christian WM, Spittal PM. The Cedar Project: acknowledging the pain of our children. Lancet 2008;373:1132-3.

15. La Rocque ED. Violence in Aboriginal communities. Ottawa (ON): Health Canada; 1994.

16. Wesley-Esquimaux CC, Smolewski M. Historic trauma and Aboriginal healing Ottawa (ON): Aboriginal Healing Foundation; 2004. Available: www.ahf.ca (accessed 2005 Oct. 23).

17. Brant-Castellano M. Reflections on identity and empowerment: recurring themes in the discourse on and with Aboriginal youth. In: Government of Canada, editors. Hope or heartbreak: Aboriginal youth and Canada's future, Ottawa (ON): Policy Research Initiative; 2008. p. 7-12.

18. Browne AJ, Smye VL, Varcoe C. The relevance of postcolonial theoretical perspectives to research in Aboriginal health. Can J Nurs Res 2005;37:16-37.

19. Dion-Stout M, Kipling G, Stout R. Aboriginal people, resilience and the residential school legacy. Ottawa $(\mathrm{ON})$ : Aboriginal Healing Foundation; 2001. Available: www.ahf.ca/newsite/english /pdf/resilience.pdf (accessed 2005 Oct. 23).

20. Roy E, Boudreau JF, Leclerc P, et al. Trends in injection drug use behaviours over 10 years among street youth. Drug Alcohol Depend 2007;89:170-5.

21. Kerr T, Miller C, Shannon K, et al. Injection drug use among street-involved youth in a Canadian setting. BMC Public Health 2009;9:171-8.

22. Canadian Institutes of Health Research. Guidelines for health research involving Aboriginal people. Ottawa $(\mathrm{ON})$ : The Institute; 2007. p. 44.

23. Miller CL, Strathdee SA, Spittal PM, et al. Elevated rates of HIV infection among young Aboriginal injection drug users in a Canadian setting. Harm Reduct $J$ 2006;3:9.

24. Miller CL, Johnston C, Spittal PM, et al. Opportunities for prevention: hepatitis $\mathrm{C}$ prevalence and incidence in a cohort of young injection drug users. Hepatology 2002;36:737-42.

25. Miller CL, Spittal PM, Frankish JC, et al. HIV and Hepatitis C outbreaks among high-risk youth in Vancouver demands a public health response. Can J Public Health 2005;96:107-8.

26. Evans JL, Hahn JA, Page-Shafer K, et al. Gender differences in sexual and injection risk behavior among active young injection drug users in San Francisco (the UFO Study). J Urban Health 2003;80:137-46

27. Miller CL, Strathdee SA, Kerr T, et al. Factors associated with early adolescent initiation into injection drug use: implications for intervention programs. J Adolesc Health 2006;38:462-4.

28. Mehrabadi A, Craib KJ, Patterson K, et al. The Cedar Project: a comparison of HIV-related vulnerabilities amongst young Aboriginal women surviving drug use and sex work in two Canadian cities. Int J Drug Policy 2008;19:159-68.

29. Chettiar J, Shannon K, Wood E, et al. Survival sex work involvement among street-involved youth who use drugs in a Canadian setting. Can J Public Health 2010;32:322-7.

30. Spittal PM, Schechter MT. Injection drug use and despair through the lens of gender. CMAJ 2001;164:802-3.

31. Zierler S, Witbeck B, Mayer K. Sexual violence against women living with or at risk for HIV infection Am J Prev Med 1996;12:304-10.

32. Barlow KJ. Examining HIV/AIDS among the aboriginal populations in Canada in the postresidential school era. Ottawa (ON): Aboriginal Healing Foundation; 2003. Available: www.ahf.ca (accessed 2007 Feb. 21).

33. Pearce ME, Christian WM, Patterson K, et al. The Cedar Project: historical trauma, sexual abuse and HIV risk among young Aboriginal people who use drugs in two Canadian cities. Soc Sci Med 2008;66:2185-94.

Affiliations: From the Faculty of Health Sciences (Miller), Simon Fraser University, Burnaby, BC; the Centre for Health Evaluation and Outcome Sciences (Pearce, Moniruzzaman, Schechter, Spittal), Vancouver, BC; the School of Population and Public Health (Pearce, Moniruzzaman, Schechter, Spittal,) University of British Columbia, Vancouver, BC; the Wuikinuxv Nation (Thomas), Port Hardy, BC; and the Splats'in/Secwepemc Nation (Christian), Enderby, BC 
Contributors: The Cedar Project Partnership consists of Aboriginal leadership and organizations that have approved the research framework, as well as this analysis. Cari Miller wrote the initial draft of the manuscript and provided oversight for the analysis. Margo Pearce was a cowriter of the initial draft and wrote subsequent revisions to the draft. Akm Moniruzzaman provided statistical expertise. Vicky Thomas made critical revisions to the manuscript. Chief Wayne Christian, Martin Schechter and Patricia Spittal were responsible for the interpretation of results and final revisions to the manuscript. All authors approved the final version of the manuscript submitted for publication.

Funding: The Cedar Project receives ongoing support from the Canadian Institutes of Health Research, which has no role in the preparation of data or manuscripts.
Acknowledgements: The authors are indebted to the study participants for their participation in the Cedar Project. Special thanks are due to the Cedar Project Partnership for their conviction and for holding the authors accountable to the voices of Aboriginal youth. To the Elders who support this study, particularly Violet Bozokoi and Earl Henderson, thank you for your continued wisdom and guidance. The study staff, Sharon Springer, Amanda Wood, Nancy Laliberte, Matt Quennville and Riel Manywounds, must be thanked for their conviction and contributions.

Members of the Cedar Project Partnership: Carrier Sekani Family Services, Healing Our Spirit, Positive Living North, Prince George Friendship Centre, Red Road HIV/AIDS Network, Vancouver Native Health Society, Central Interior Native Health, Splats'in Secwepemc Nation 